\title{
$\widehat{A T} \mid$ SCHOOL OFLAW

Volume 6

Number 4 Student Articles Edition

Article 2

2020

\section{Egg Donation: What Egg-Xactly Is It? Property or a Service?}

Sally Fritz

Texas A\&M University School of Law (Student), sallyfritz@tamu.edu

Follow this and additional works at: https://scholarship.law.tamu.edu/journal-of-property-law

Part of the Property Law and Real Estate Commons

\section{Recommended Citation}

Sally Fritz, Egg Donation: What Egg-Xactly Is It? Property or a Service?, 6 Tex. A\&M J. Prop. L. 25 (2020).

This Student Article is brought to you for free and open access by Texas A\&M Law Scholarship. It has been accepted for inclusion in Texas A\&M Journal of Property Law by an authorized editor of Texas A\&M Law Scholarship. For more information, please contact aretteen@law.tamu.edu. 


\title{
EgG Donation: What EgG-Xactly Is It? Property OR A SERVICE?
}

\author{
By: Sally Fritz ${ }^{\dagger}$
}

\begin{abstract}
The tax characterization of income from human body transfers is a perplexing conundrum. There is no definitive case law or statute that informs taxpayers how to treat these transfers. Legal scholars have discussed the issue of how to treat human body transfers such as eggs, sperm, blood, etc. for decades, and the Internal Revenue Service has still not acted to provide any sort of clarity. This Comment discusses the historical tax implications on various types of human body transfers, outlines some of the distinguishing factors between characterizing a transfer as property or a service, provides an argument for why income from egg donation should be characterized as a service, and finally, discusses how a definitive characterization will affect the regulation of egg donation and lead to an increase in the research of overall health effects from egg donation.

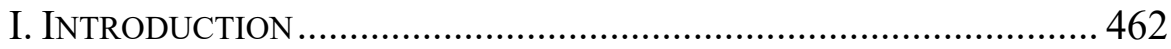

II. HISTORICAL TAX IMPLICATIONS ON DONATIONS OF

HUMAN BODY PARTS 463

A. Tax Implications on Blood/Plasma Donation ................... 463

1. United States v. Garber ............................................ 464

2. Green v. Commissioner............................................ 466

3. Lary v. United States............................................... 468

B. Tax Implications on Sperm Donation ........................... 469

C. Tax Implications on Egg Donation ............................... 471

1. Pre-Perez .................................................................. 471

2. Perez v. Commissioner .......................................... 472

III. DistingUiSHING FACTORS BETWEEN

PROPERTY AND SERVICE

DOI: https://doi.org/10.37419/JPL.V6.I4.2

$\dagger$ J.D. Candidate, Texas A\&M University School of Law, Spring 2020. The Author would like to thank Dean Terri Helge for serving as her faculty advisor and offering her feedback and guidance throughout the writing process. The Author would also like to thank Professor Brian Larson for teaching her fundamental legal research and writing skills and for being a fantastic mentor throughout her legal education.
\end{abstract}


IV. REASONS EGg Donation SHOULd BE

CONSIDERED A SERVICE

A. Understanding the Egg Donation Process ......................... 477

B. Arguments for Egg Donation Being Characterized as a Service.

V. How CHARACTERIZING EGG DONATION AS A SERVICE AFFECTS

THE REGULATION OF EGG DONATION

A. Why There Needs to Be More Regulation on Egg Donation.

B. How the Fixed Characterization as a Service Will Affect Regulation....

VI. CONCLUSION 486

\section{INTRODUCTION}

"It's not all glitz and glamour for sure, it's not even a way to make some quick cash. You have to believe in what you are doing, be informed about the health risks and other issues down the road." 1 These are the words of one woman who has transferred her human eggs eight times to recipients hoping to start a family. ${ }^{2}$ This woman's words are important to understanding taxation on the process commonly known as egg donation. Until 2015, the Tax Court had not provided any guidance to how egg donors could be taxed. ${ }^{3}$ However, in Perez v. Commissioner, the Tax Court rejected the notion that an egg donor could exclude from her gross income the compensation she received from egg donation as pain and suffering damages. ${ }^{4}$ While the court in this case provided an answer as to that specific type of tax deduction a taxpayer could attempt to claim, they still left open the question of whether egg donation should be considered a transfer of property or a service given to those in need since the issue was outside of the chief concern of the case. ${ }^{5}$

There are important implications to the characterization of egg donation as property or service. If egg donation is characterized as a service, it is subject to ordinary income rates and also may be subject

\footnotetext{
1. Let's Make a Baby, MellFire Blog (Nov. 19, 2009), https://mellfirecom.wordpress.com/2009/11/19/lets-make-a-baby/ [https://perma.cc/X4C8-SJC2].

2. Id.

3. See Perez v. Comm'r, 144 T.C. 51, 56-57 (2015).

4. Id. at $62-63$.

5. Id.
} 
to self-employment tax rates. ${ }^{6}$ Comparatively, if egg donation is characterized as a transfer of property, then it may be subject to a better rate than the ordinary income rate if it qualifies as a long-term

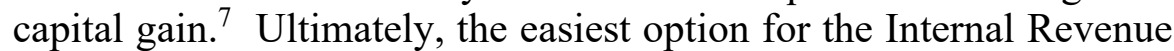
Service ("IRS") is to characterize egg donation as a service because of the administrative difficulties that would be involved if egg donation were to be characterized as property. ${ }^{8}$ Once the IRS decides to characterize egg donation as a service, it will open the door to a greater amount of regulation in the egg donation process.

This Comment provides a commentary on the taxation of egg donation and offers reasons why egg donation should be treated as a service rather than a transfer of property. Part II of this article traces the historical tax implications on human body material transfers, specifically that of blood, sperm, and eggs. Additionally, Part II discusses in greater detail the case of first impression, Perez $v$. Commissioner. Part III discusses the various distinguishing factors between the tax characterization of property and a service. Part IV explains the reasons that egg donation should be considered a service rather than property. Part $\mathrm{V}$ discusses how the solidification of characterizing egg donation as a service will affect the regulation of egg donation and why greater regulation is necessary to address the health risks associated with egg donation. Specifically, it addresses the current issues with the lack of real regulation on egg donation, which endangers those who are donors because the long-term effects of egg donation are unknown. Then, it discusses how a definitive characterization of egg donation as a service how will allow for further regulation. Finally, Part VI briefly concludes and summarizes the main points of the article.

\section{HistORICAL TAX IMPLICATIONS ON DONATIONS OF HUMAN BODY PARTS}

\section{A. Tax Implications on Blood/Plasma Donation}

The tax system's treatment of human body material transfers has not always been clear to either donors or legal commentators. ${ }^{9}$ Blood

6. See I.R.C. $\S 1402$ (2012).

7. See id. $\S 1222$.

8. See infra SECTION IV.

9. Let's Make a Baby, MellFiRe Blog (Nov. 19, 2009), https://mellfirecom.wordpress.com/2009/11/19/lets-make-a-baby/ [https://perma.cc/X4C8-SJC2]. See also LAWRENCE ZelenAK, Law and Markets 
donation was the first type of human body transfer to receive any definitive tax treatment. ${ }^{10}$ Specifically, the IRS decided that no deduction was available to a blood donor, regardless of whether they donated their blood to a charitable institution. ${ }^{11}$ The IRS stated as its reasoning for this conclusion:

Accordingly, allowable deductions are confined to donations of money and of things which are generally thought of as being comprehended by the term "property" as distinguished from the value of services rendered. It has been a long established policy of the Internal Revenue Service not to allow a deduction for the value of services rendered to charitable institutions. See O.D. 712, C.B. 3, 188 (1920). The Comptroller General of the United States in considering the question of reimbursement for blood transfusions has ruled that a blood transfusion involves the rendering of a personal service by the donor rather than the sale of a commodity. See 5 Comp. Gen. 658 and 888. In view of the foregoing, it is held that furnishing blood for a transfusion or to a blood blank is analogous to the rendering of a personal service by the donor rather than a contribution of "property" and the fair market value of blood donated by an individual to a charitable institution is not deductible as a charitable contribution under section 23(o) of the Internal Revenue Code. ${ }^{12}$

Even with this clear statement from the IRS that it categorizes blood donation as a service rendered rather than a sale of property, there has been a variety of contradicting case law that discusses what happens when people exchange their blood/plasma for compensation.

\section{United States v. Garber}

The first important case to discuss concerning blood/plasma donation is United States v. Garber where the Tax Court discussed that the sale of plasma was income as a sale of property, but it did not come to a definitive conclusion on that issue. Garber was a unique case involving criminal tax evasion by Ms. Dorothy Clark Garber. ${ }^{13}$ In the late 1960s, Ms. Garber discovered that her blood contained a rare antibody, which aided in producing a blood group typing serum. ${ }^{14}$

the Body in Question: The Income Tax and Human Body Materials, 80 LAW \& CONTEMP. PROB. 37 (2017).

10. See Rev. Rul. 162, 1953-2 C.B. 127.

11. Id.

12. Id. at 128 .

13. United States v. Garber, 607 F.2d 92, 93 (5th Cir. 1979).

14. Id. 
A manufacturer who had made the discovery invited her to enter into a contract for the sale of her blood plasma where they would pay her for each attempt at drawing plasma based on the strength of the plasma. ${ }^{15}$ Other manufacturers realizing the rarity of the antibody in Ms. Garber's blood began attempts to lure her away from the original manufacturer by offering her greater amounts of money. ${ }^{16}$ So, Ms. Garber began working with three manufacturers and gave her plasma in exchange for compensation. ${ }^{17}$ One company gave her a regular weekly salary of $\$ 200$ subject to withholding taxes and provided Garber with a W-2 form. ${ }^{18}$ Ms. Garber attached the W-2 to her tax return and paid taxes on that weekly salary. ${ }^{19}$ However, all other compensation she received from the exchange of her plasma, both from the company giving her the weekly salary and the other two only paying her for the plasma itself, was given to her directly by check. ${ }^{20}$ Ms. Garber did not include the amounts of compensation she received by check as income on her tax return, which the IRS found to be tax evasion. $^{21}$

One of the issues that this court addressed concerning that income was whether the plasma exchange was a sale of property or the rendition of a service. ${ }^{22}$ While the court did not come to a conclusion on this issue, it discussed some of the reasoning behind deciding to characterize it one way or another. ${ }^{23}$ As arguments for why the court could consider her activity as performance for a service, the court spoke to how Ms. Garber's plasma had to be artificially stimulated, which can cause nausea and dizziness. ${ }^{24}$ The court also described how the process of extracting plasma can be extremely painful if a nerve is struck, which can cause nausea, blackouts, dizziness, scarring, and can increase the risks of blood clotting and hepatitis. ${ }^{25}$ The court stated that these efforts "logically compare to the performance of a service." ${ }^{26}$ Additionally, as part of the discussion for characterizing Ms. Garber's actions as a taxable personal service, the court discussed

15. Id. at $93-94$.

16. Id. at 94 .

17. $I d$.

18. $I d$.

19. $I d$.

20. Id.

21. Id.

22. Id. at 95 .

23. Id. at 97 .

24. Id.

25. Id

26. Id. 
how an IRS agent spoke on how a Revenue Ruling stated that donations of blood are a service for purposes of determining the deductibility of a charitable contribution and in his opinion Ms. Garber's actions were similar to that of someone donating their blood. $^{27}$

As arguments for why the court could consider Ms. Garber's activity a sale of property, they stated that blood plasma is similar to that of a chicken's eggs, a sheep's wool, or any salable part of the human body. ${ }^{28}$ Therefore, it is tangible property that in this case commanded a selling price dependent on its value, i.e., the strength of the desired antibodies in the plasma. ${ }^{29}$ The court stated that Ms. Garber was paid more for the greater the concentration of the antibodies in her blood regardless of any pain suffered, work done, or time spent, which would lead to the conclusion that plasma exchange was a tangible sale of property. ${ }^{30}$ However, the court ultimately decided that it was not necessary for them to decide how to definitively categorize plasma exchange for tax purposes in this case, since it was one for criminal charges of tax evasion. ${ }^{31}$ Nonetheless, the confusion of the categorization for the sale of plasma brought forth by this court was revisited in the following year in Green v. Commissioner. ${ }^{32}$

\section{Green v. Commissioner}

Green v. Commissioner was the first case where a court truly dictated that the exchange of blood plasma for compensation should fall into the category of a sale of tangible property rather than the performance of services. ${ }^{33}$ This case concerned a woman living in Florida, Margaret Cramer Green, who possessed a rare blood type. ${ }^{34}$ She received a great deal of compensation for her plasma because she had such a rare blood type. ${ }^{35}$ The compensation she received was such a large amount that she relied on selling her plasma as her primary source of income. ${ }^{36}$ During the year in question, she had made ninety-

27. Id. at 96 .

28. Id. at 97 .

29. $I d$.

30. Id.

31. Id. at 100.

32. See generally Green v. Comm'r, 74 T.C. 1229 (1980).

33. $I d$.

34. Id. at 1230 .

35. Id.

36. Id. 
five donations of plasma. ${ }^{37}$ Since she was relying on these exchanges as income and therefore needed to be sure her body was healthy enough to continue giving plasma, Ms. Green supplemented her diet with high protein diet foods. ${ }^{38}$ On her tax return for the year, Ms. Green claimed \$7,170 as her gross income for donating plasma. ${ }^{39}$ She attempted to deduct $\$ 2,355$ of that amount as related business-expense deductions, including the amount she paid for the high protein diet foods. ${ }^{40}$ As part of deciding how much Ms. Green owed the IRS, the court determined that her activity constituted the sale of property rather than the rendering of a service. ${ }^{41}$

When stating its reasoning, the court included a discussion on how petitioner simply passively released fluid from her body, which made the exchange similar to that of the usual sale of a product by a manufacturer to a distributor. ${ }^{42}$ Specifically, they state:

The rarity of petitioner's blood made the processing and packaging of her blood plasma a profitable undertaking, just as it is profitable for other entrepreneurs to purchase hen's eggs, bee's honey, cow's milk, or sheep's wool for processing distribution. Although we recognize the traditional sanctity of the human body, we can find no reason to legally distinguish the sale of these raw products of nature from the sale of petitioner's blood plasma. ${ }^{43}$

While the Tax Court in this case determined that plasma donation such as this constituted a sale of property, it still appears that blood donation falls into the category of a service. The court did not seem to want to change the overarching idea that blood donation is a service because it stated when making its conclusion "under the facts of this case" rather than making a claim that all those engaging in blood or plasma donation are engaged in a sale of property. ${ }^{44}$ Arguably, it also makes a difference that this case constituted plasma being given solely to receive regular compensation rather than any altruistic feelings that tend to coincide with the idea of donation. The court was not finished with providing contradicting case law regarding blood/plasma transfers because six years later it decided Lary v. United States.

37. Id. at 1231

38. $I d$.

39. Id. at 1230 .

40. Id. at 1231 .

41. Id. at 1234 .

42. Id.

43. Id.

44. Id. 


\section{Lary v. United States}

In Lary v. United States, the court once again discussed the possible characterizations of blood donation, but it refused to conclude on the issue because it was not essential to the overarching issue of the case. Lary involved a doctor who attempted to claim a deduction for the value of a pint of blood donated to the Red Cross in $1976 .{ }^{45}$ The Tax Commissioner refused this deduction and claimed that the donation of blood constituted the performance of a service, which "expressly does not qualify as a charitable contribution under the regulations." 46 On appeal, Dr. Lary attempted to argue that the Tax Commissioner was incorrect that blood donation constituted a service, and he argued that blood donation is the contribution of property. ${ }^{47}$ The Eleventh Circuit Court of Appeals refused to determine whether the donation of blood constituted a service rendered or the contribution of a product since Dr. Lary could not claim the charitable deduction either way. ${ }^{48}$

The court explained that the charitable contribution deduction was disallowed if they considered blood donation a service because the tax regulations expressly deny charitable deductions for the performance of services. ${ }^{49}$ Additionally, the court explained that if they considered blood donation the contribution of property, the charitable contribution was still prohibited because the Internal Revenue Code of $1954^{50}$ "provided that the amount of any charitable contribution of property shall be reduced by 'the amount of gain which would not have been long-term capital gain if the property contributed had been sold by the taxpayer at its fair market value (determined at the time of such contribution)." "51 They further explain how the application of the Code language would mean that if the property donated to charity would have resulted in ordinary income or short-term capital gain to the donor if the property had been sold rather than "charitably contributed," the donor's charitable deduction would not include any amounts attributable to such gain, but rather would be limited to his adjusted basis in the property. ${ }^{52}$ The court goes on to say how Dr.

45. Lary v. United States, 787 F.2d 1538, 1539 (11th Cir. 1986).

46. $I d$.

47. Id.

48. $I d$.

49. Id. at 1539-1540. See also 26 C.F.R. § 1.170A-1(g) (2019).

50. It is important to note that while this court was using language from the Internal Revenue Code of 1954, the language did not change in the Internal Revenue Code of 1986 and is still applicable law. See I.R.C. § 170(e)(1)(A) (2012).

51. Lary, 787 F.2d at 1540 (quoting I.R.C. § 170(e)(1)(A)).

52. Id. 
Lary did not offer any evidence to the court as to any basis in the blood he donated. ${ }^{53}$ Additionally, he did not offer any evidence that the holding period for blood is more than six months, which at that time was the requirement for the holding period of a capital asset to qualify as a long-term capital gain. ${ }^{54}$

Therefore, with the lack of evidence showing the holding period and the basis that Dr. Lary held in the blood, the court concluded that he was not able to receive a charitable contribution deduction for his blood donation to the Red Cross. ${ }^{55}$ The court in this case also reiterated the holding in Green v. Commissioner that the sale of blood does give rise to income as defined in Section 61 of the Internal Revenue Code. ${ }^{56}$ However, the court ultimately admitted that it was leaving open the question of how to categorize the sale or contribution of blood as either a service rendered or contribution of property. ${ }^{57}$

These three cases on the treatment of blood/plasma donations do not provide any definitive advice to taxpayers or tax lawyers on how to report income received from these types of donations. Instead, the reader of these cases is left in a state of confusion as to how to properly characterize such human body transfers.

\section{B. Tax Implications on Sperm Donation}

There has been limited case law on the tax treatment of sperm donation. The cases regarding the tax treatment of sperm have been in regards to whether a person could leave their sperm to another person in their will. ${ }^{58}$ However, the tax implications for income received from sperm donation have not been as controversial as that of egg donation. ${ }^{59}$ In part, this seems to be in relation to the fact that the process for sperm donation is not as lengthy or physically cumbersome as it is for egg donation. ${ }^{60}$ Additionally, sperm donors

\section{Id.}

54. Id.

55. Id.

56. $I d$. at 1541 .

57. Id. at 1540 .

58. See Hecht v. Kane, 20 Cal. Rptr. 2d 275 (Cal. Ct. App. 1993).

59. While there is not controversy for sperm donors as far as the tax implications of income from sperm donation, there is still controversy among legal scholars on the regulation of sperm donation. See generally Vanessa L. Pi, Regulating Sperm Donation: Why Requiring Exposed Donation Is Not the Answer, 16 DUKE J. GENDER L. \& POL. (2009); Jacqueline M. Acker, The Case for an Unregulated Private Sperm Donation Market, 20 UCLA WOMEN's L. J. 1 (2013).

60. See generally, Sperm Donation Overview, MAYO CLINIC, https://www.mayoclinic.org/tests-procedures/sperm-donation/about/pac-20395032 
are paid significantly less than egg donors. ${ }^{61}$ However, it seems likely that sperm donation would be treated similarly to egg donation because the language on sperm donor websites is similar to that of egg donor websites. $^{62}$ The donation centers are careful to state that they will compensate donors for their "time," "effort," and even go so far as to state "it is not payment for the use of your sperm." 63 This language clearly is trying to persuade the reader that in no way should the donated sperm be considered the thing that they are receiving payment for. Instead, the websites highlight the fact that they are helping future families and the donor should feel as though they are "providing one of life's greatest gifts" by donating sperm. ${ }^{64}$ It further makes sense to characterize sperm donation as a service because of the likelihood that sperm donors donate multiple times in a way that it does not make sense to characterize sperm donation as a one-time sale of property. Many sperm donation clinics have their compensation plans set up in a way that sperm donors are paid monthly and must donate weekly. ${ }^{65}$ Finally, as discussed below, it does not make sense to treat sperm any differently than an egg if both the sperm and the egg contain the necessary genetic material to create a human being. ${ }^{66}$ Instead, it would make sense to characterize these donations as a service with the possibility that they would be subject to the selfemployment tax. ${ }^{67}$

[https://perma.cc/3QVX-TS3N] (last visited Sep. 13, 2019).

61. See infra SECTION IV.

62. Compare Sperm Donor Compensation, CALIFORNIA CRYOBANK DONOR SPERM BANK http://www.spermbank.com/why-donate/sperm-donor-pay [https://perma.cc/3NS3-JE8V] (last visited Sep. 13, 2019) ("Cryobank reimburses your time and expenses with compensation”), with For Egg Donors FAQ, CTR. FOR HUM. REPROD., https://www.centerforhumanreprod.com/egg-donation/donors/faqs [https://perma.cc/HM8Z-GBC6] (last visited Sep. 13, 2019) ("compensation for your time, commitment, and services").

63. Your Compensation, CRYOS, https://usa.cryosinternational.com/become-adonor/become-a-sperm-donor/your-compensation [https://perma.cc/C3S2-V6E8] (last visited Sep. 13, 2019).

64. Id.

65. Sperm Donor Compensation, CALIFORNIA CRYOBANK DONOR SPERM BANK, http://www.spermbank.com/why-donate/sperm-donor-pay [https://perma.cc/3NS3JE8V] (last visited Sep. 13, 2019).

66. See infra SECTION IV.

67. See Becoming a Sperm Donor FAQs, CALIFORnia Cryobank DONOR SPERM BANK, http:/www.spermbank.com/sperm-donor-faqs [https://perma.cc/XR66-WXHP] (last visited Sept. 13, 2019) (A 1099 is given for purposes of self-employment tax). See also I.R.C. § 6017 (2012). 


\section{Tax Implications on Egg Donation}

The question of the tax treatment of egg donors affects legal scholars, tax lawyers, and accountants, but it also affects the taxpayers who are donating their eggs as a way of helping those who want to have a family. ${ }^{68}$ Instead of donors being able to spend the money they receive as compensation for the painful process they must endure as they wish, they are later discovering that there are serious tax implications on the compensation they receive. ${ }^{69}$ One woman talked about her experience with taxation on the compensation she received from donating and how after doing months of research, she was still unaware that the money she received was taxable income. ${ }^{70}$ This woman is not alone in her confusion. The confusion of what the tax implications are for egg donation has been a running commentary among legal scholars for decades. ${ }^{71}$

\section{Pre-Perez}

Before Perez in 2015, there had been no case law regarding egg donation and how donors should classify the compensation they received. However, there was still a plethora of commentary from legal scholars regarding what they thought the tax treatment of egg donors should be. ${ }^{72}$ In determining the tax treatment of egg donation, many deliberated between the proper characterization of egg donation as a sale of property or compensation for services rendered. ${ }^{73}$ However, since the Tax Court decision in Perez, there have been a couple of legal scholars who have continued to advocate for treating

68. Egg Donation and My Personal Tax Hell, MellFire Blog (April 15, 2012), https://mellfirecom.wordpress.com/2012/04/15/egg-donation-and-my-personal-taxhell/ [https://perma.cc/N7FY-BX2S].

69. Id.

70. Id.

71. See generally, Lisa Milot, What Are We-Laborers, Factories, or Spare Parts? The Tax Treatment of Transfers of Human Body Materials, 67 WASH \& LEE L. REV. 1053 (2010); Danielle A. Vera, R-Egg-Ulation: A Call for Greater Regulation of the Big Business of Human Egg Harvesting, 23 MICH. J. GENDER \& L. 391 (2016); Carol L. Williamson, Poached Eggs: The Misclassification of Egg Donors as Independent Contractors and How Egg Donors Can Contribute to the Argument for a New Category of Worker-The Dependent Contractor, 51 GA. L. REV. 327 (2016); Jay A. Soled, The Sale of Donors' Eggs: A Case Study of Why Congress Must Modify the Capital Asset Definition, 32 U.C. DAVIS L. REV. 919 (1999).

72. Id.; see generally Zelenak supra note 9.

73. Soled, supra note 71 (arguing that egg donation should be characterized as property). See also Zelenak, supra note 72 (arguing that egg donation should be characterized as property). 
egg donation as a sale of property rather than compensation for services. $^{74}$

\section{Perez v. Commissioner}

Perez v. Commissioner provides a definitive conclusion for only one possible deduction that egg donors could possibly claim. In 2015, the Tax Court answered in a case of first impression whether an egg donor could deduct compensation received for egg donation under the Tax Code deduction for damages received on account of personal physical injuries or physical sickness. ${ }^{75}$ This case concerned egg donor, Nichelle Perez, a twenty-nine-year-old single woman from Orange County, California, who had heard about egg donation in her early twenties, which led her to search for a facility where she could donate her eggs. ${ }^{76}$ After doing some internet research, Ms. Perez decided to use a California company called "The Donor Source" as her egg-donation agency. ${ }^{77}$ Ms. Perez subsequently donated her eggs twice through this agency, receiving $\$ 20,000$ in compensation. ${ }^{78}$ When filing her taxes for that year, she did not include the $\$ 20,000$ on her tax return because she was under the impression that the money was not taxable because it was damages for pain and suffering. ${ }^{79}$ The Commissioner disagreed with this classification and sent Ms. Perez a notice of deficiency, which Ms. Perez petitioned. ${ }^{80}$ The court in the case specifically states that it knows scholars have discussed the tax implications of egg donation, but it claims "[i]t does not require us to decide whether human eggs are capital assets. It does not require us to figure out how to allocate basis in the human body, or the holding period for human-body parts, or the character of the gain from the sale of those parts." The court states it only must distinguish whether the payment was in exchange for the pain, suffering, and physical injuries she endured or whether she received compensation for services rendered. Ms. Perez argues that it should be the former, while the Commissioner argues for the latter.

74. See Zelenak, supra note 9 (arguing that egg donation should be characterized as property); Bridget Crawford, Tax Talk and Reproductive Technology, 100 B.U. L. REV., (last revised Aug. 26, 2019), https://papers.ssrn.com/sol3/papers.cfm?abstract id=3231578.

75. Perez v. Comm'r, 144 T.C. 51 (2015).

76. Id. at 52

77. Id.

78. Id. at 56 .

79. Id.

80. Id. 
The basis for Ms. Perez's argument stemmed from the contractual agreements between both herself and The Donor Source and herself and the anonymous recipients of her unfertilized eggs. ${ }^{81}$ The Donor Source explained that all payments made to egg donors are dependent on prospective parents picking the particular donor. Once the donor was chosen, the donor must sign two contracts, one with The Donor Source and one with the prospective parents. The contract agreement with The Donor Source stated:

Donor Fee: Donor and Intended Parents will agree upon a Donor Fee for Donor's time, effort, inconvenience, pain, and suffering in donating her eggs. This fee is for Donor's good faith and full compliance with the donor egg procedure, not in exchange for or purchase of eggs and the quantity or quality of eggs retrieved will not affect the Donor Fee.

In addition to this statement, which meant that Ms. Perez would receive compensation regardless of whether her eggs were viable or not, the contract stated that the fee "shall not in any way constitute payment to Donor for her eggs." The contract between Perez and the prospective parents was consistent with that of The Donor Source and provided that her payment was "in consideration for all of her pain, suffering, time, inconvenience, and efforts." Finally, the contract stated that it did not instruct any of the parties on the issue of taxation of any payment made or received for the egg transfer.

In concluding that the compensation Ms. Perez received did not constitute damages for personal physical injury or physical sickness, the court admits that Ms. Perez did suffer from the process. ${ }^{82}$ Specifically, the facts stated that the hormone injections bruised and hurt her and burned the entire time she was injecting them. ${ }^{83}$ Additionally, every time she had to administer another dose of the hormones, she had to search for a spot on her stomach that was not already covered in bruises. ${ }^{84}$ When she had to have the final shot of $\mathrm{hCG}$, she experienced significant physical pain deep in her muscles as well as extreme abdominal bleeding. ${ }^{85}$ Finally, Ms. Perez stated that after the removal of the eggs, she felt cramped and bloated and was suffering from mood swings, headaches, nausea, and fatigue. ${ }^{86}$

81. Id. at 53-54.

82. Id. at 62 .

83. Id. at 55 .

84. Id

85. Id.

86. Id. 
However, even though the court admitted that Ms. Perez suffered from the process, it held that since she had voluntarily signed a contract to receive compensation for enduring this pain and risk to her health, the money she received did not constitute "damages." 87 While the court shied away from making any definitive statements regarding the proper tax treatment of egg donation other than to say that it did not constitute damages for personal physical injury or physical sickness, the court did discuss that in this case it had to admit that Perez received compensation for services rendered and not for the sale of property. ${ }^{88}$ In drawing this conclusion, the court drew distinctions from both Green and Garber, which have been discussed in detail above. The court stated that since Perez's compensation depended on neither the quantity nor the quality of the eggs retrieved but solely on how far into the egg-retrieval process she went that her compensation was not for sale of property. ${ }^{89}$ However, while stating that it had to find that her compensation was for services rendered, it countered that statement by saying that it was not deciding that issue in this case because it was unnecessary for the argument it was chiefly concerned with since Ms. Perez was trying to argue that egg donation should be excluded from her income altogether rather than talking about the character of the income. ${ }^{90}$ Perez definitively gave us the conclusion that compensation from egg donation does fall into the broad definition of gross income under the Internal Revenue Code. ${ }^{91}$ However, Perez still left open the question on how the IRS will ultimately characterize the income from egg donation, but it certainly strengthened the argument that it should be considered a service.

\section{Distinguishing Factors BetweEn Property AND SERVice}

Before discussing the factors that the IRS looks to in deciding whether to characterize income as coming from the transfer of property or coming from a service rendered, it is important to understand why such a characterization matters. If the IRS considers the donation a transfer of property, then the income received can qualify as a capital gain. ${ }^{92}$ Gains from capital assets, or capital gains, have the potential to be subject to a lower tax rate than ordinary

87. Id. at 62 .

88. Id. at 57.

89. Id.

90. $I d$.

91. See I.R.C. § 61(a) (2012).

92. Id. $\S 1221$. 
income. ${ }^{93}$ Comparatively, gains from a service rendered are subject to ordinary income rates and cannot be a capital asset. ${ }^{94}$ Additionally, gains from a service could also be subject to self-employment taxes, which requires the net earnings from self-employment to be taxed at a rate of $15.3 \%{ }^{95}$ However, to be subject to self-employment taxes, a taxpayer must be seen as earning income from self-employment, which is unlikely in the context of egg donation. ${ }^{96}$ Understanding the possible implications of each distinction leads to an understanding of how the courts and IRS decide whether to characterize income as coming from either property or service.

Since the IRS has not issued any concrete law or policy as to how to characterize income from egg donation, one looks to case law and legal scholars to grasp what goes into the characterization. The most recent case to discuss the property vs. service debate is of course, Perez. ${ }^{97}$ In that case, the Tax Court commented that the egg donor received compensation for services rendered and not for the sale of property. ${ }^{98}$ The court cited as three factors in reaching their conclusion: (1) the agreement of the characterization between the taxpayer and the Commissioner; (2) the insistence on the services label in the contracts between The Donor Source and the taxpayer; and (3) the contractual allocation to the Donor Source, rather than to the taxpayer, of the risk that no eggs, or only unusable eggs, could be extracted. $^{99}$ While the court found these factors to be determinative that Perez received compensation for services rendered, these factors do not seem to be usable in every case. Therefore, one looks to prior case law for a better understanding of the differentiation between property and service.

In a prior case, the Tax Court turned to dictionary definitions in determining whether a taxpayer rendered a service or made a donation of property. ${ }^{100}$ According to the definitions used in that case, "property" is "something that is or may be owned or possessed, the exclusive right to possess, enjoy, and dispose of a thing," and

93. See id.

94. See id.

95. See id. § 6017. See also id. § 1401(a)-(b)(1).

96. See id. § 1402(a), which states that "net earnings from self-employment means the gross income derived by an individual from any trade or business carried on by such individual." Egg donation is unlikely to be viewed as a trade or business unless someone does it regularly enough to make it their sole source of income.

97. See Perez, 144 T.C. 51.

98. Id. at 57.

99. See id. at 51.

100. See Holmes v. Comm'r, 57 T.C 430 (1971). 
"something to which a person has legal title."101 The dictionary in that case defined "services" as "acts done for the benefit or at the command of another," "actions that further some end or purpose," conduct "that assists or benefits someone or something," and "deeds useful or instrumental to some object."102

In addition to the definitions used above, one legal scholar argues in making the distinction between property and service in regards to human body materials that it matters how much personal participation is involved and whether the income in question is derived from something with an "undeniable thingness." "103 This scholar admits that when looking at personal participation, i.e, the self-creation and the extraction of one's human body material, then it suggests the performance of a service. ${ }^{104}$ However, he also goes on to argue that when looking at the "undeniable thingness" of the resulting human body material once extracted that it should be considered as property because of its "ready alienability and transferability." 105

Another legal scholar uses two different analogies in forming her opinion that human body transfers should be considered property. ${ }^{106}$ First, she says that human beings could potentially be portrayed as being a laborer, therefore performing services. ${ }^{107}$ In contrast, as a position in favor of property, she points to the idea that human beings are factories producing spare parts available for sale. ${ }^{108}$ She also later goes on to explain that in her viewpoint "human body materials removed from a living person and transferred in a commercial transaction are property; to the extent they are transferred gratuitously or disposed of, they are not property."109 However, what she seems to fail to take into account is the fact that egg donors receive compensation not for the egg itself, but rather for the time, pain, and effort that goes into the donation process. Additionally, if as in Perez, egg donors receive compensation prior to any extraction of the egg, it seems her argument would also fail in characterizing the egg as property because she herself says that the egg is not property until extracted. While she is clearly arguing that egg donation is a

\footnotetext{
101. Id. at 436 .

102. Id.

103. Zelenak, supra note 9, at 52.

104. Id.

105. Id.

106. See Milot, supra note 71 , at 1090-91.

107. Id. at 1091 .

108. Id.

109. Id. at 1092.
} 
commercial transaction rather than a gratuitous transfer, this logic does not seem to fit into the egg donation process discussed below. ${ }^{110}$ Knowing the factors that the IRS and legal scholars consider in determining whether a taxpayer has received compensation for services rendered or transfer of property, it seems clear that income from egg donation should be considered a service.

\section{Reasons EgG Donation Should Be Considered A Service}

\section{A. Understanding the Egg Donation Process}

Before describing the reasons that the IRS should consider egg donation a service, it is essential to understand the process of egg donation. The process of egg donation is not one that women are encouraged to take lightly. It is a process that takes several months, requires administering painful injections every day, and comes with emotional as well as physical consequences. ${ }^{111}$ Typically, the first steps in the egg donation process involve an application, interview, physical examination, blood tests, drug tests, an ultrasound, a medical and psychological history, infectious disease screening, and a screening for inherited disease. ${ }^{112}$ If a donor has HIV, hepatitis C, is a carrier of the cystic fibrosis gene, or is at risk of inherited disease, then she will not be eligible to donate. ${ }^{113}$ Once the potential donor passes through this process, then the donor clinic places them on the list as an optional donor for prospective parents. ${ }^{114}$

After a prospective parent selects the donor, both women must sync their menstrual cycles. ${ }^{115}$ In order to accomplish this, the donor will either take a birth control pill or self-administer daily injections of a

110. See infra SECTION IV.

111. Let's Make a Baby, MellFire Blog (Nov. 19, 2009), https://mellfirecom.wordpress.com/2009/11/19/lets-make-a-baby/

[https://perma.cc/X4C8-SJC2]; See also, What I Wish I Knew Before I Donated My

Eggs, WEAREEGGDONORS.COM (Nov. 13, 2015), http://www.weareeggdonors.com/blog/2015/11/13/what-i-wish-i-knew-before-idonated-my-eggs [https://perma.cc/N98A-VRPJ].

112. Jayne Leonard, How Does the Egg Donation Process Work? MEDICAL NEWS TODAY https://www.medicalnewstoday.com/articles/314750.php [https://perma.cc/CJ8A-HGM6] (last updated Mar. 22, 2019).

113. Id.

114. Egg Donation: How Egg Donation Works, CTR. For HuM. REPROD. https://www.centerforhumanreprod.com/egg-donation/how-it-works/ [https://perma.cc/RD7J-5GNF] (last visited Mar. 2, 2019).

115. Id. 
drug called Lupron to suppress her natural cycle. ${ }^{116}$ During this time, donors may experience side effects such as headaches, bloating, increased breast size, and breast tenderness. ${ }^{117}$ Once she receives notice that she and the recipient have synced, the donor goes into the ovarian stimulation phase and must begin self-administering injections of a different drug called gonadotropin to stimulate her ovaries. $^{118}$ This drug allows for more than one egg to mature for retrieval, which is optimal for donation. ${ }^{119}$ The donor must also inject the drug into a fatty spot on the body, so for many smaller donors they choose to inject in their stomachs. ${ }^{120}$ However, since they have such a small amount of body fat, they are usually injecting into the same bruised spot day after day. ${ }^{121}$ During this time, donors may experience side effects including bruising at the injection site, mood swings, and tender breasts. $^{122}$ Additionally, donors are at risk for their ovaries going into hyperstimulation, so they must be monitored closely through blood tests and ultrasounds. ${ }^{123}$

After one of the donor's ultrasounds shows that the donor's eggs have developed sufficiently, the donor will trigger ovulation through an injection of hCG. ${ }^{124}$ This prepares the donor for egg removal, which is accomplished in a short procedure. ${ }^{125}$ The procedure is done while the donor is asleep, and a physician inserts an ultrasound probe transvaginally and uses a needle to remove the egg from each follicle. ${ }^{126}$ After the procedure, the donor receives instructions to take

116. Id.; Here I Go Again, MellFire Blog (Dec. 14, 2009), https://mellfirecom.wordpress.com/2009/12/14/here-i-go-again/

[https://perma.cc/XY9Y-279A].

117. Ride 'em Cowgirl, MellFire Blog (Jan. 4, 2010) https://mellfirecom.wordpress.com/2010/01/04/ride-em-cowgirl/ [https://perma.cc/AZR6-7M88].

118. Egg Donation: How Egg Donation Works, CTR. FOR Hum. ReProd., https://www.centerforhumanreprod.com/egg-donation/how-it-works/

[https://perma.cc/RD7J-5GNF] (last updated Jan. 8, 2015).

119. Id.

120. What I Wish I Knew Before I Donated My Eggs, We ARE EGG DonORS: EGG DONOR STORIES, http://www.weareeggdonors.com/blog/2015/11/13/what-i-wish-iknew-before-i-donated-my-eggs [https://perma.cc/N98A-VRPJ] (last visited Sept. $15,2019)$.

121. Id.

122. Leonard, supra note 112.

123. Egg Donation: How Egg Donation Works, CTR. FOR Hum. ReProd., https://www.centerforhumanreprod.com/egg-donation/how-it-works/

[https://perma.cc/RD7J-5GNF] (last updated Jan. 8, 2015).

124. Id.

125. Id.

126. Id. 
the rest of the day to rest and recover. ${ }^{127}$ However, during this time, donors are at risk for developing a condition called Ovarian Hyperstimulation Syndrome ("OHSS"). ${ }^{128}$ One donor talks about her experience with OHSS and how she had been told that it was rare, yet when she returned to the doctor's office a week post-surgery, she describes that the nurse "didn't sound too surprised." During this time, she experienced severe bloating, pulsing pain, and vomiting. ${ }^{129}$

While these are the physical experiences that women endure during the process of egg donation, there are also emotional ones. Women are able to feel that they have changed someone's life by giving them the opportunity to have a child that they would have been unable to have without the help of their eggs. ${ }^{130}$ This rewarding feeling that women have from the experience can encourage them to disregard the physical toll that egg donation takes on their body, which helps them to make the decision to donate again. ${ }^{131}$ While there are certainly rewarding and happy emotional experiences for egg donors, there are also the long-term emotional choices that a donor must make. Sometimes a donor may choose to sign contracts allowing their biological offspring to seek her out once they turn twenty-one if they choose to. ${ }^{132}$ Making such a decision impacts their future children, their future spouse, as well as other family members who do not understand that they will not receive continuous photos or life updates from the children created by their eggs. ${ }^{133}$ Since there are a multitude of both physical and emotional impacts on egg donation, women should not go into the process lightly, and it appears to be one of the greatest gifts that a woman could give to a set of prospective parents. It follows from the understanding of this process that egg donation fits squarely into a service rather than a sale of property.

127. Id.

128. What I Wish I Knew Before I Donated My Eggs, WE ARE EGG DonORS: EGG DONOR STORIES, http://www.weareeggdonors.com/blog/2015/11/13/what-i-wish-iknew-before-i-donated-my-eggs [https://perma.cc/N98A-VRPJ] (last visited Sept. 15, 2019); Ovarian Hyperstimulation Syndrome, MAYO CLINIC, https://www.mayoclinic.org/diseases-conditions/ovarian-hyperstimulationsyndrome-ohss/symptoms-causes/syc-20354697 [https://perma.cc/8E3U-D9Q8] (last visited Sept. 14, 2019).

129. Id.

130. Id.

131. Id.

132. Let's Make a Baby, MEllFire Blog (Nov. 19, 2009), https://mellfirecom.wordpress.com/2009/11/19/lets-make-a-baby/ [https://perma.cc/X4C8-SJC2].

133. See id. 


\section{B. Arguments for Egg Donation Being Characterized as a Service}

If courts have previously been willing to consider blood donation as a rendering of a personal service, then it follows that other human body material transfers should be treated in a similar way. Especially a human body material transfer that ultimately goes towards the creation of a human being. We ethically shy away from the idea that human beings can be regarded as property, so why should something that is essential to the creation of a human being be considered property? A variety of legal scholars have made their opinions on this debate known. ${ }^{134}$ The majority of them make arguments that compensation from egg donation should be considered a sale of property. ${ }^{135}$ However, in their discussions they ignore the fact that the eggs they are considering "property" contain the genetic material necessary to create a new human life. Some of the scholars mention the fact that society shies away from treating humans as property, the moral implications of considering an egg property, etc. However, aside from one brief mention of these issues, they do not go any deeper when discussing the reasoning they find persuasive that eggs once excised from the donor's body are property and should be taxed as such. ${ }^{136}$

If the IRS categorizes eggs as property, then it will have to discuss what is the basis of the egg, what is the holding period, whether the transfer of property is subject to gift tax, and finally, whether considering gametes as property affects the estate tax. Determining all of this information would be a great administrative headache for those involved and will likely lead to a great state of confusion among taxpayers, particularly concerning whether everyone would have to consider the value of their gametes and whether to include them in their gross estate when they die. Comparatively, if the IRS decides to categorize egg donation as a service, it will have to discuss whether this means the egg donor is an independent contractor and whether the egg donor is subject to the self-employment tax, which would make this income subject to a significant tax rate. ${ }^{137}$ However, since the egg donors most likely will not be taking part in the process more than a few times in their lifetime and are not engaging in a trade or business, it does not seem logical to subject them to the self-employment tax rate. Therefore, it would be easiest to simply categorize egg donation

134. See generally, Crawford, supra note 74, Zelenak, supra note 9, Soled, supra note 71 .

135. Id.

136. Id.

137. I.R.C. $§ 1401$ (2012 \& Supp. 2017). 
as a service and make it income that is subject to the ordinary income tax rate rather than attempting to decide the holding period, basis, and whether gametes can be subject to the estate tax.

Additionally, it is important to acknowledge the argument that the treatment of sperm donation differs vastly from the treatment of egg donation. ${ }^{138}$ For one thing, sperm donation does not involve near as much time as egg donation. ${ }^{139}$ Egg donors are giving away months of their time to the process of giving away a piece of their anatomy that eventually goes on to form a human being, whereas the process of sperm donation is over in the matter of at most a couple of hours. ${ }^{140}$ However, the real discrepancy in the treatment of sperm and the treatment of eggs is in terms of payment. On average, sperm donors receive around $\$ 100-125$ per donation, ${ }^{141}$ whereas egg donors receive around $\$ 8,000-14,000 .{ }^{142}$ With such a vast difference in the amount that they receive for their human body material, it is nonsensical to argue that they are being paid for a piece of property. How are we, as a society, to make sense of the notion that one half of a human being is valued as being worth significantly less than the other half. The answer is that we cannot, but that is exactly what the argument that egg donation should be considered a sale of property encourages us to do. However, it is likely that the property-argument proponents will argue that the reason for the wide difference in payment is because of the wide abundance of sperm in the male body and the finite amount of eggs in the female body. While this argument certainly has some merit, it is not persuasive considering the ultimate "product" or "property" being donated is still one half of a human being. Even if this argument was persuasive, it still does not support such a wide variance in the amount of money that sperm donors and egg donors are paid. It is clear that the real compensation for egg donors is for their time and the pain they agree to endure in order to help the hopeful prospective parents.

138. See infra SECTION II B.

139. It is general knowledge that sperm donors are able to go through the screening process and then go in and donate, which takes at most a few hours of time and as stated above egg donation takes months.

140. See infra SECTION IV A.

141. Meredith Davies, How Much Money Can You Make Donating Sperm?, TOUGHNICKEL, https://toughnickel.com/self-employment/make-money-donatingsperm (last updated Jan. 11, 2019).

142. For Egg Donors: FAQ, CTR. FOR HuM. REPROD., https://www.centerforhumanreprod.com/egg-donation/donors/faqs (last visited Sept. 10, 2019). 
One of the legal scholars who is a proponent of the property categorization additionally argues that egg donors have a fake altruistic narrative surrounding their donation. ${ }^{143}$ She argues that egg donors are women who see the amount that egg donation clinics will pay them, which is what ultimately determines their decision to take part in the process. ${ }^{144}$ Therefore, she asserts that this lack of altruism further adds to the argument that courts should treat egg donation as a sale of property rather than a service. ${ }^{145}$ However, even entertaining this notion that egg donors do not have an altruistic motivation behind donation, it does not say anywhere in the Internal Revenue Code or any case law that for something to be considered a service, the person profiting from the rendering of a service must be motivated by something other than money. Additionally, it is a rational argument that while some donors may not have an altruistic motivation when they first decide to give their eggs, they may change their minds after the initial round of shots that cause intense bloating and cramps if only to convince them to keep going with the process.

The next argument to make that egg donation should be categorized as a service rather than property is the common idea that you cannot sell your organs or human body parts. ${ }^{146}$ If the legal system already prohibits people from selling their kidneys or other organs on the black market, then what would make the sale of eggs different? How would this be legal, but the sale of a kidney is not? The only way that we can rationalize this from a legal standpoint is that the compensation that egg donors receive is not for the egg itself, but rather it is from the entire process that the egg donor agrees to endure. Instead of receiving payment for their eggs, they receive payment for their time and the discomfort they experience throughout the process. Additionally, as further evidence of this argument, one only has to look to the contract from Perez or the egg donation websites to see that the donation centers are extremely careful to avoid saying that the egg donor is receiving compensation for the egg that is being extracted. ${ }^{147}$ Rather, they say the donors receive compensation for their "time and effort." 148 It follows that the reason the clinics are careful to phrase it

143. See Crawford, supra note 74 , at 108.

144. Id.

145. Id.

146. 42 U.S.C. $\$ 274$ e (2012).

147. See infra Section III. See also How It Works, World EgG BAnK, https://www.theworldeggbank.com/donors/how-it-works/ (last visited Mar. 2, 2019).

148. How It Works, WORLD EGG BANK, 
this way is both because of the ethical implications they want to avoid of baby selling and also because of the fact that the sale of human organs is illegal. Therefore, based on the legal treatment of organs, it logically follows that income received from the donation of eggs should be considered a service.

Finally, the traditional basic concept of property is the notion of a bundle of sticks, which can be understood with the metaphor of owning a home. When a person owns a home, they generally own the land the home is built on, the mineral rights surrounding the home, and the home itself as well as everything inside of the home. All of these rights are considered to be the "bundle of sticks" of property that they own. If they were to sell some of their mineral rights, they would be giving away some of their sticks. When trying to fit human body parts, such as blood, eggs, and organs, into this idea of a bundle of sticks, they do not fit nicely because of the difficulty in differentiating when our ownership of certain "sticks" within the "bundle" would begin and end. For example, if our overall human body is the "bundle," then would we begin ownership when we are created or when we are able to be cognizable of ownership of our body parts? Making this determination seems like it would create controversy that the IRS would likely wish to avoid. Ultimately, it is the most logical argument that the income donors receive from giving their eggs to wanting families should be treated as a service because they are not receiving compensation for the human body material itself, but rather for the time and pain they have had to endure in the process.

\section{How Characterizing Egg Donation as a SERvice AfFects THE REGULATION OF EGG DONATION}

\section{A. Why There Needs to Be More Regulation on Egg Donation}

The long-term physical effects of egg donation on donors' bodies are still fairly unknown. ${ }^{149}$ Many are concerned about whether donors become infertile or develop cancer in their colon or uterus later in life. ${ }^{150}$ While egg donors undergo a similar process to those who

https://www.theworldeggbank.com/donors/how-it-works/ (last visited Mar. 2, 2019).

149. Catherine Elton, As Egg Donations Mount, So Do Health Concerns, TIME (Mar. 31, 2009). See also Emily Woodruff, “We Simply Don't Know”: Egg Donors Face Uncertain Long-Term Risks, STAT, https://www.statnews.com/2017/01/28/egg-donors-risks/ [https://perma.cc/5B73ZBKE] (Jan. 28, 2017).

150. Elton, supra note 149. 
undergo in vitro fertilization ("IVF") (hormone injections and other drugs that stimulate ovaries, promote egg maturation, and prevent the release of eggs before they are retired), $\backslash$ and there are studies that show IVF is safe, there still seems to be a call for more studies to be done on the effects of egg donation. ${ }^{151}$ Additionally, many IVF patients continue to be monitored throughout the process, whereas egg donors are monitored for a couple days post-surgery and then are never contacted again. ${ }^{152}$ Often when donors make the decision to offer their eggs to prospective recipients, they are motivated by both a desire to see another person create a family and being in a difficult financial situation. ${ }^{153}$ Generally, donors are motivated by financial situations such as tuition expenses, inability to make home mortgage payments, and a desire to make life a little easier for themselves. ${ }^{154}$ The issue with egg donation is that they are not aware of the health risks that egg donation can pose both short-term and long-term. ${ }^{155}$ Short-term side effects of egg donation include OHSS, ovarian torsion, or ruptured ovarian cysts. ${ }^{156}$ Long-term side effects of egg donation include endometriosis, infertility, and ovarian fibroids. ${ }^{157}$ These effects are not insignificant for donors, and egg donation is becoming increasingly popular. ${ }^{158}$

While the Center for Disease Control and Prevention has begun requiring fertility clinics to report statistics on egg donors such as weight, height, age, ethnicity, and their history of egg donation, this is not enough to address the long-term health issues that egg donors may be forced to deal with. ${ }^{159}$ Additionally, there are psychological risks which the American Society for Reproductive Medicine vaguely describes as "complex." The lack of knowledge about both the physical and psychological health for donors support the fact that there

151. Id. See also Woodruff, supra note 149, stating that while the process for IVF and egg donation is similar, the people who undergo the procedures are usually completely different from a health point of view because those undergoing IVF already are faced with fertility problems and egg donors are not.

152. Elton, supra note 149.

153. Id.

154. Id.

155. Id.

156. Id.

157. Woodruff, supra note 149.

158. Id. (stating that in 2010 there were more than 18,000 donor cycles recorded and in 2014 there were 20,481 with experts anticipating that number to continue to rise as women wait until later in life to start a family.).

159. $I d$. 
is a need for more regulation on egg donation or at the very least a greater amount of research devoted to the subject.

\section{B. How the Fixed Characterization as a Service Will Affect Regulation}

If the IRS designates income from egg donation as a service, then there are more resources available to expend on things like getting both doctors and egg donors more informed about the process of egg donation. More regulation on the industry means that more families can benefit from egg donation by being able to start a family and more donors can benefit because they will be more aware of the overall tax consequences on the compensation that they receive from donating as well as the possible health risks involved. It has been found that many egg donation clinics actually benefit from providing conflicting advice to egg donors on how to treat the income they receive from the donation process. ${ }^{160}$ Therefore, distinguishing egg donation as a service will not disadvantage the overall regulation of the egg donation process. Rather, it will help the regulation of egg donation because fertility clinics will all have to inform the donors of the tax consequences for egg donation in a uniform way.

The fertility market continues to rise as more couples are seeking aid to create a family with the help from a donor. ${ }^{161}$ If this market continues to rise as it has been and there is still a disconnect in how donors should report the income they receive, it logically follows that issues such as the one from Perez and the blog posts described throughout this Article will become more prevalent. To avoid cases such as Perez from reoccurring, the IRS should clarify how they would like taxpayers to treat the income they receive from egg donation. There is understandable hesitancy in providing a definitive characterization of all human body transfers. However, there does not appear to be a large issue with providing a definitive characterization for egg donations alone, and the easiest characterization to apply is that of a service.

160. Crawford, supra note 74.

161. The Number of Women Seeking Egg Donors Continues to Rise, OPEN ARMS SURROGACY \& EGG DONATION, https://www.openarmssurrogacy.com/the-numberof-women-seeking-egg-donors-continues-to-rise/ [https://perma.cc/2MT3-QS2T] (last visited Feb. 17, 2019). 


\section{CONCLUSION}

In this Comment, it has been the goal to educate the reader on the historical tax treatment of human body transfers, including egg donation. If the fertility market continues to rise as it has within the last several years, more and more egg donors will face the confusion that is the tax implications on their transfer. While several scholars argue that egg donation should be treated as a property transfer and therefore become subject to gift or estate tax, the tax commissioner had it correct in Perez when he stated that egg donation is a service and should therefore receive ordinary income tax treatment. However, this Comment aims to aid in legal scholars' efforts to convince the IRS to provide a definitive characterization on egg donations, regardless of whether they conclude egg donations are a transfer of property or a service to provide better regulations and health studies of the egg donation process. Ultimately, though, the best way to characterize egg donations is to say that they are a service. 